\title{
変敗油の調理に及ぼす影響(第13 報) Influence of Rancid Oil on the Cooking (Part 13)
}

\section{変敗油による揚げ鯨肉のたん白質の変性および消化率について Studies on Denaturation and Digestibility of Protein in Whale Meat Fried with Rancid Oil}

\section{梶本五 郎 谷田博美 (Goroh Kajimoto) (Hiromi Tanida)}

\begin{abstract}
The properties of whale meats fried at $170^{\circ} \mathrm{G}$ for 4 minutes with rancid or nonrancid soybean oils were compared.

The digestibility of protein of those fried with rancid oil was greater than those with non-rancid oil. Lowering of the solubility in water and decrease of the amount of cystine were especially remarkable in those with rancid oils.
\end{abstract}

\section{腥言}

野菜㧍よび肉類の油揚げなどで揚げ油を何度も使用し ていると，次第に加熱重合され，粘稠性を帯びてくる。 あるいは空気中に放置していると，次第に変敗してく る。気がつかぬ内に，このような变敗油を使用している ことが多い。著者らは変敗油を使用したときの調理に及 ぼす影響について，3〜4 ${ }^{1}$ 報告してきた。引続き一連 の研究として，今回肉類を揚げた場合の変化について調 べた。

まず栄荃学的考察の面から，予め未変敗油および変敗 油で油場げした鲸肉のたん白質の消化性を調へ，変敗油 揚げ鲸肉の方が消化性よく，その原因がたん白変性によ るものと考えた。

たん白変性の研究は, 従来多くの研究者により行なわ れ，Hardy2) は加熱によって起こるとのべ, Chich, Ma $\mathrm{rtin}^{3)}$ らは力学的な説明を行ない, Mines, Thomas, Norvis らは重金属によっても起こるとし,さらに Hopkins は機械的な振盜でも变性すると報告している。そ して変性の結果, 溶解度の堿少が起こると Wu到)はの心゙, Mirsky, Anson5) はSH の出現と, その定量を行ない， Bateman は，たん白水解酳素によって消化されやすく なると報告し, Linderström-Lang6) および Lundgren?) は加熱変性を受けた場合，ペプチド連鎖がより簡単な結 合になっているため, 酳素作用が受けやすくなったので
あろうと報告している。

これらの観点から, 変性の尺度である溶解率, シスチ ン量, SH 基の定量を試みた結果, 変敗油揚げ鯨肉のほ うが，溶解率およびシスチン量が減少し，すなわちたん 白変性度合が大きいことを知り，たん白変性と消化性に ついて一知見を得たので，それらの結果を報告する。

\section{実 験 の 部}

\section{1. 試料および試料の調整}

揚げ油として大豆油を選び，大豆油に乾燥した空気を 吹込み変敗油を調整した。その性状は第 1 表のとおりで ある。

第1表揚げ油の性状

\begin{tabular}{|c|c|c|c|}
\hline 性 状 & 試料 油 & 末変敗油 & 変敗大豆油 \\
\hline 過酸化物価 & M. E $/ \mathrm{kg}$ & 5.9 & 220 \\
\hline 価 & & 0.6 & 6.8 \\
\hline 战化 価 & & 196.4 & 186.2 \\
\hline 沃 素 価 & & 135.1 & 106.8 \\
\hline
\end{tabular}

揚げ肉として市販冷凍赤鯨肉を選び，10 $\mathrm{cm}^{2}$, 厚さ 0.7 ๓⿴のものを揚げた。

油揚げした鯨肉は, 直ちに倍量のエーテルにて 3 回洗 滌 (生鯨肉中の油脂量とほぼ同量になる。)したものと, さらにンッグスレーにて10時間抽出し, 完全に脱脂した 鯨肉を、それぞれ乳鉥にてすりつぶしたものについて， 
第2表供试鲸肉の一般成分

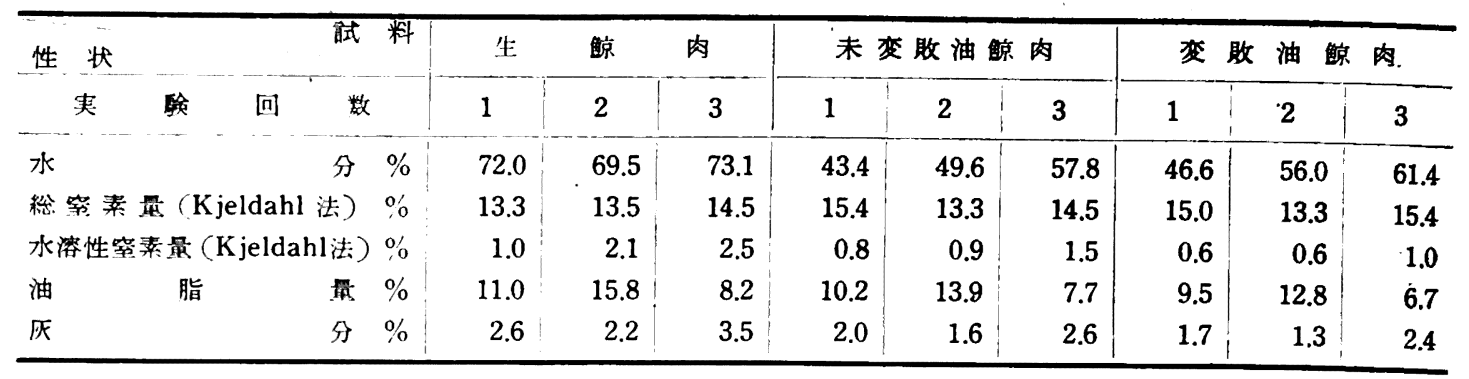

消化試験，溶解率，シスチンおよび SH 基定量などに供 した。

供試鯨肉の名称を便宜上，3回エーテルにて油脂分を 簡眥に除いたもの卡，变敗油鯨肉，変敗油鯨肉々呼称 し，ソックスレーにて10時間抽出した鯨肉在，生脱脂鯨 肉, 未变敗油脱脂鲸肉, 変敗油脱脂鯨肉上それぞれ呼称

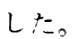

$$
\text { それらの一般成分は第 } 2-3 \text { 表のとおりである。 }
$$
策 3 表脱脂鲸肉の成分

\begin{tabular}{|c|c|c|c|c|c|c|}
\hline 試 料 & \multicolumn{2}{|c|}{ 生脱脂鯮肉 } & \multicolumn{2}{|c|}{$\begin{array}{l}\text { 条変敗油 } \\
\text { 脱脂鯨肉 }\end{array}$} & \multicolumn{2}{|c|}{$\begin{array}{l}\text { 変敗 油 } \\
\text { 脱脂鯨肉 }\end{array}$} \\
\hline 実毁回数 & 1 & 2 & 1 & 2 & 1 & 2 \\
\hline 水 分 \% & 61.8 & 63.4 & 22.9 & 20.0 & 22.3 & 21.2 \\
\hline 総究案量\% & 14.8 & 15.2 & 16.0 & 15.6 & 158 & 15.3 \\
\hline
\end{tabular}

なお総窒素量, アミ，態窒素量，水溶性空素，溶解率 なビは，全乾物に対する百分率で表わした。

水溶性空素量は浴比 $1: 50$ で 5 時間浸涉後, 求めた。

生鲸肉に比心，油掦げ鯨肉の総窒素量が増加してい る。恐らく加熱により他の成分の減少により增加した か, あるいは油脂中の複合たん白質が揚げ物に吸着した ため上考えられる。また変敗油処理は灰分の減少がいち しるしく，油脂中の遊離酸により溶解したと考えられ るっこのことは揚げ油の着色と関倸あるように思われる ので，以上のことについては别報する。

なお抽出した各鯨肉の過酸化物価および酸価は, 生鯨 肉で過酸化物価が 100.2 ，末変敗鯨肉で 135, 変敗油鯨油 で113，酸価はそれぞれ，16.5，21.5，33.7であった。

2. 実騃方法

1)揚げ方

$2 l$ 入の鉄鍋中に各油脂を $1 l$ すついれ，末変敗油およ

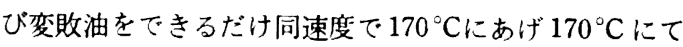
4 分間鯨肉を揚げた。なお 4 分間は，食事に適した揚げ の時間であった。

口) 消 化 性

生鯨肉 $2 \mathrm{~g}$, 各油あげ鯨肉をそれぞれ $1 \mathrm{~g}$ ずつとり，大 高8)の方法にしたがい， $\mathrm{pH}$ を 8.6 に調整し，次に $0.5 \mathrm{~g}$
のパンクレアチンを加え， $38^{\circ} \mathrm{C} に て 24$ 時間消化せしぬ た。消化の程度を比較するには Pope-Stevens の加銅法 によりアミノ態空素量を求め，消化率として比較する場 合も大高の方法に準した。すなわち，同方法を記載する 上, 消化後中和し， $10 \% \mathrm{CCl}_{3} \mathrm{COOH}$ 溶液 $30 \mathrm{ml}$ を加え な㧍水にて全容を $250 \mathrm{~m} l$ となしたる後, 港過し，Kjeld一 ahl 法によって定量し（この空素量をaとする），別に試 料 $2 \mathrm{~g}$ ないし $1 \mathrm{~g}$ に水 $220 \mathrm{ml}$ およひ $10 \% \mathrm{CCl}_{3} \mathrm{COOH}$ 溶液 $30 \mathrm{ml}$ を加えて, 直ちに港過したものについて, 消化前 の可溶性窒素菎を定量し（b)，またパンクレアチンの 芧素は消化試験に用いたものと同量 $0.5 \mathrm{~g}$ をとりここれに. $0.05 \mathrm{~N}-\mathrm{NaOH}$ 溶液および水を加えて, 全容を $200 \mathrm{ml}$ と し，次にこれを中和してから，10\% $\mathrm{CCl}_{3} \mathrm{COOH}$ 溶液 30 $\mathrm{ml}$ を加え，さらに水にて全容を $250 \mathrm{ml}$ となし，この港 液の一定量について空素量を定量する（c）。消化率は $a-(b+c)$ 試料の全窒素一 $\mathrm{b} \times 100$ より算出した。

八）溶解性について

それぞれの鯨肉を $2 \mathrm{~g}$ ずつとり，水 $100 \mathrm{~m} l$ を加え， $40{ }^{\circ} \mathrm{C}$ テ 5 時間，放圈後の水に溶解する量を求めた。 放置途中は 30 分毎に捙汼した。

二）溶液の $\mathrm{pH}$

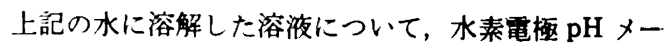
ターで測定した。

なお使用した水の $\mathrm{pH}$ は 6.8 のものである。

ホ）シスチンの定量

シスチンがリンタングステン酸と反応して，青色を示 すので，その䈨淡を光電比色計にて定量した。

すなわち, 生鯨肉 $2 \mathrm{~g}$, 未変敗油鲸肉および変敗油鯨肉 を $1 \mathrm{~g}$ ずつとり， $130^{\circ} \mathrm{C}$, 油浴中買流冷却器下， $20 \%$ 埴 酸 $10 \mathrm{ml}$ を加え, 三角フラスコ中で 4 時間加水分解す る。加水分解の着色はカオリン約 $300 \mathrm{mg}$ で振ることによ り，大部分は脱色される。若干の着色は測定時において 数倍にて希䣋されるから，測定誤差にはいらない。また カオリンはシスチンを吸着しない。カオリンを数回水洗 し，滤液に $20 \% \mathrm{NaOH}$ を加えて $\mathrm{pH}$ を 6.0 にし，その流 液を適当に希釈して発色させた。 


\section{へ) $\mathrm{SH}$ 基定}

各郭内 $1.5 \mathrm{~g}$ を $60 \mathrm{ml}$ 詹の着色すり合わせ瓶にとり, 蒸 溜水 $15 \mathrm{ml}$ を加えて照濁せしめ，これに 0.1 モルの第一 および第二リンサンソーダの等量溶液を $10 \mathrm{ml}$ 加えて pH6.8 に調整し， 0.1 モルのフェリシアン加里 $1 \mathrm{ml}$ を加え て, よく层鳘し, $40^{\circ} \mathrm{C}$ で 20 分間放圈後, $10 \mathrm{ml}$ の蒸溜水 と, $10 \mathrm{ml} の 0.1 \mathrm{~N}$-三塩化酢酸とを加え， 10 分間放置せ る後，淇過し，遊離したSH-groupをもって，Ferricyanide を選元し，Ferrocyanide とし，これと硫酸第 二铁と反応させ, Prussian blue の比色法により求めた。

\section{実験結果および考察}

未変敗油および変敗油（II）であげた鯨肉の栄学的 考察の面から，まず消化性を比較した。その結果第 4 〜 5 表のとおりである。

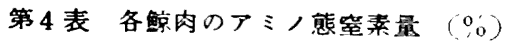

\begin{tabular}{|c|c|c|c|c|c|c|}
\hline 実 酮 回 & 数 & 1 & 2 & 3 & 平均 & 指 数 \\
\hline 踣 & 内 & 4.8 & 5.2 & 5.6 & 5.2 & 100.0 \\
\hline 未変敗油鲸 & 肉 & 5.6 & 6.0 & 5.7 & 5.8 & 111.6 \\
\hline 変 敗 油 鲸 & 肉 & 5.8 & 6.8 & 6.4 & 6.3 & 121.0 \\
\hline
\end{tabular}

第 5 表 アミノ恶窒菜量よりみた消化性 アミノ憼窒素量 全空素量

\begin{tabular}{|c|c|c|c|c|}
\hline 陚料 実験数 & 1 & 2 & 3 & 平均 \\
\hline 䣼 & 36.1 & 38.5 & 38.5 & 37.7 \\
\hline 末変敗油鲸肉 & 36.2 & 45.0 & 40.0 & 40.4 \\
\hline 変敗油鲸内。 & 38.6 & 51.2 & 41.7 & 43.8 \\
\hline
\end{tabular}

3 回の各実験共，生鲸肉に比心，油揚げ钴肉の方が消 化性よく，特に変敗油鲸肉の方が消化性がよかった。 次いで消化率をみると第 6 表のとおりである。 第 6 表 各鲸内の消化率 $(\%)$

\begin{tabular}{|c|c|c|c|c|}
\hline 证料 実筑数 & 1 & 2 & 3 & 平 均 \\
\hline 鯨 & 61.8 & 63.1 & 63.4 & 63.0 \\
\hline 未変敗油鯨肉 & 62.0 & 72.5 & 65.0 & 66.5 \\
\hline 㚆敗 油 鯨 肉 & 62.9 & 74.2 & 79.2 & 72.1 \\
\hline
\end{tabular}

消化性同様, 消化率も変敗油鲸肉の方が良以。

脱脂觡肉の消化性をみると第 7〜9表のとおりである。

第 7 表 各脱脂鮊内中のアミ, 態空素量 $(\%)$

\begin{tabular}{|c|c|c|c|c|c|c|}
\hline 武料 実験数 & 1 & 2 & 平 & 均 & 指 & 数 \\
\hline \multirow{3}{*}{ 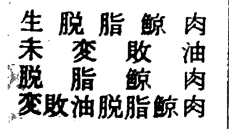 } & 6.9 & 6.3 & & 6.5 & & 100 \\
\hline & 6.7 & 6.4 & & 6.5 & & 100 \\
\hline & 7.5 & 6.9 & & 7.2 & & 110 \\
\hline
\end{tabular}

第 8 表各脱脂鯨肉の消化性

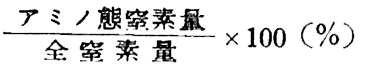

\begin{tabular}{|c|c|c|c|}
\hline 試 料 䨋 弱 & 1 & 2 & 平 \\
\hline 生 脱 脂 鲸 内 & 46.6 & 41.3 & 44.0 \\
\hline 未变敗油脱脂鲸肉 & 42.0 & 41.0 & 41.5 \\
\hline 㚆敗油脱脂鯨 肉 & 47.7 & 45.1 & 46.4 \\
\hline
\end{tabular}

第 9 表 各脱脂鯨肉の消化祽 $(\%)$

\begin{tabular}{|c|c|c|c|}
\hline 夹酸 数 & 1 & 2 & 均 \\
\hline 脱 脂 鲸 内 & 73.8 & 71.4 & 72.6 \\
\hline 末変敖油脱脂鲸肉 & 71.1 & 72.2 & 71.6 \\
\hline 变敗油脱脂鲸肉 & 75.6 & 74.7 & 75.2 \\
\hline
\end{tabular}

消化性，消化㳯共に変敗油脱脂鯨肉のほうが，末変敗 脱脂鯨肉より良い。また脱脂しない鯨肉に比・，消化 性，消化摔共によくなっていることは，脱脂したため か,あるいは脱脂のための抽出時間，温度なとの原因に より良くな、たものと推察される。ただし，生脱脂鯨肉 に比心，末変敗油脱脂鯨肉の消化率は沶ずかながら減少 した。

一般に油あげ鯨肉の方が生鯨肉より消化性良く，油揚 げ時の加熱の影瑟と考えられる。

このように加熱による消化性については，従来より研 究がなされ, Grinley ${ }^{9)}$ は種々の調理で処理した牛肉の 消化を人間について実験した結果，消化率に差がなく， $80 \sim 85^{\circ} \mathrm{C} に 2 \sim 5$ 時間水募し，ペプシンの消化試験で は大差ないが, 生肉よりは消化よく, 恐らく水浴性空素 化合物か゚多少失なわれたためであろう上報告している。

Talarico ${ }^{10)}$ も生肉, 煮肉上も消化性には变わりないと

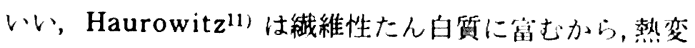
性しても消化性が変わらないのだと報告している。

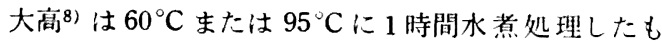
のは，生の牛肉に比心，その消化性は変わらないが, $120^{\circ} \mathrm{C}$ に 1 時間処理したものは, 消化害が非常に低下寸 ると報告している。Linderström-Lang ${ }^{6)}$ 扩よび Lundgren $^{7)}$ の報告のように加熱変性を受けた場合, ハプチド 連鎖がより簢単な結台になっているため，酵素作用が受 けやすくなったのであろう。また，Cohn'12) は加熱卵白 はトリプシンまたはペプシンとトリプシンによって30分 以内にきわめて早く消化されると報告している。

以上加熱による消化性は，各研究者により異なるよ5 で，加熱によるたん白変性の有無, 変性度台, 凝固現象 などによって相違したものと考えられる。

著者らのように油揚げ $\left(170^{\circ} \mathrm{C}, 4\right.$ 分間) による肉の消 
化性の報告はほとんど見ず，高温，短時間処理によって たん白変性が起こっているか，また起こっているとすれ ば，変敗油は酸化物，過酸化物などを含むゆえ，その変 性度合も異なるものと推察される。そこで一般的な変性 特徴として, 溶解性, シスチン量およびSH 基などにつ いて調べてみた。

まず溶解性とその溶液の $\mathrm{pH}$ をみると，第10１1表の とおりである。

第 10 表 各鯨内 $の$ 溶解性 (\%)

\begin{tabular}{|c|c|c|c|c|c|}
\hline 头験数 & 1 & 2 & 3 & 平均 & 指 \\
\hline 肉 & 33.2 & 30.9 & 27.8 & 30.6 & 100.0 \\
\hline 末变敗油鲸肉 & 10.7 & 18.3 & 21.0 & 16.6 & 54.2 \\
\hline 変敗油鲸肉 & 9.5 & 13.6 & 15.7 & 12.9 & 42.1 \\
\hline
\end{tabular}

第 11 表 淮 液 $の ~ \mathrm{pH}$

\begin{tabular}{|c|c|c|c|c|c|}
\hline 实䮖数 & 1 & 2 & 3 & 平 & 均 \\
\hline 鿷 & 6.2 & 6.0 & 5.9 & & 6.0 \\
\hline 末变敗油鲸肉 & 5.7 & 5.8 & 5.8 & & 5.8 \\
\hline 变敭油鯮肉 & 5.4 & 5.6 & 5.2 & & 5.4 \\
\hline
\end{tabular}

生鲸肉:二比心，油揚!鲸肉の溶解性はいちじるしく娍 少し、三の娍少染は変敗油鯨肉のほうが大きい。

溶液の $\mathrm{pH}$ は, 変敗油鯨肉の方が酸性側にあった。 シスチン量を求めると第 12 表のとおりである。 第 12 表 各鯨内中のシスチン量 $(\%)$

\begin{tabular}{|c|c|c|c|c|c|}
\hline 実験数 & 1 & 2 & 3 & 平均 & $\left.\begin{array}{c}\text { 分解率 } \\
(0 \\
0\end{array}\right)$ \\
\hline 肉 & 0.94 & 0.97 & 1.08 & 1.00 & 0 \\
\hline 末 変 敗 油 鲸肉 & 0.92 & 0.93 & 0.94 & 0.93 & 7 \\
\hline 変 敭 油鯨 豽 & 0.90 & 0.89 & 0.91 & 0.90 & 9 \\
\hline
\end{tabular}

末変敗油鯨肉, 変敗油鯨肉共, 生鯨肉に比ベシスチン 量が減少している。その減少率は変敗油鯨肉の方が大き い。恐らく加熱およびその他の因子により，シスチンが 分解したものと考えられる。

通常 S-S 結合の切断は, 還元㓮, 加熱蒸気 (電笠の理 論), 酸化剂の濃度の高いような場合および過度の伸張 により切断されるが，油揚げの場台は加熱之，変敗油中 の酸化物および過酸化物らが働き，S-S に攻揧し未変敗 油鯨肉よりもシスチンを多く分解したもの上推察され る。

したがってシスチンの分解と溶解性の減少から，たん 白変性が起こったものと思われ, その変性度は変敗油鯨 肉のほうが大きい。

シスチンが分解すれば，分解に比例し SH 基が増加す ると考えられるので, SH 基を求めた。

その結果は第 13 表のとおりである。

第 13 表各鲸肉中の $\mathrm{SH}$ 基是

\begin{tabular}{|c|c|c|c|c|}
\hline - & & & \multicolumn{2}{|c|}{ (モル数) } \\
\hline 試料 実酸数 & 1 & 2 & $3^{\prime}$ & 平 均 \\
\hline 鯜 内 & $10^{-3}$ & $10^{-3}$ & $10^{-3}$ & $10^{-3}$ \\
\hline 末变敗油鲸肉 & $10^{-2}$ & $9 \times 10^{-3}$ & $10^{-2}$ & $10^{-2}$ \\
\hline 変敋 油鯨肉 & $10^{-2}$ & $5 \times 10^{-3}$ & $7 \times 10^{-3}$ & $7 \times 10^{-3}$ \\
\hline
\end{tabular}

生鯨肉中の SH 基より, 油掦げ鯨肉中の SH 基のほ5 が增加しているのはシスチンの分解に比例し, 増加した ものと考えられる。ところがシスチンの分解に比例する とすれば，変敗油鯨肉の方が SH 基が多くなければなら ないのに末変敗油鯨肉より少なくなっている。恐らくい ったんできた SH 基がさらに油脂中の酸化物により分解 されたものと考えられる。

以上の結果からぬて変敗油鯨肉の方が，たん白変性度 大きく，したがって消化性が良くなったと思われる。 次いで油脂の変敗度と消化性をみると，第 1 図のとお りである。

第 1 図 油脂の変敗度と掦げ鯨内の消化性

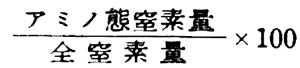

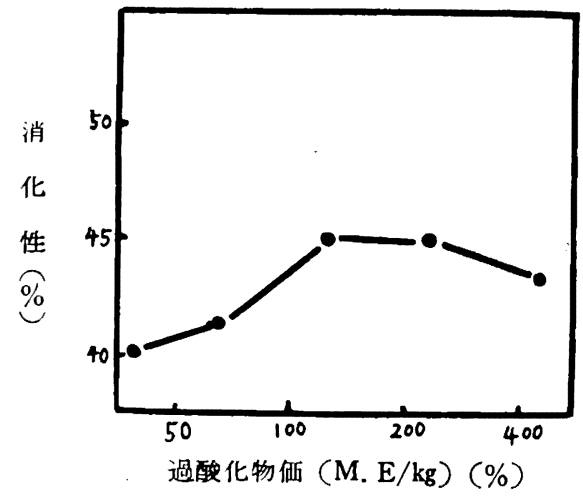

油脂の変敗にしたがい徐々に消化性は良くなり，過酸 化物価 100 から 170 までは同消化性を示し，200以後に なるとかえって消化性がわるくなってくるようで，ある 程度以上たん白変性が起これば消化性が劣るものと考え られる。しかしどの程度の変性が起これば，消化性がよ くなり，あるいは逆にわるくなったりするのかはなお決 定しがたく, かつ使用する鯨肉の新鮮度, 掦げ肉の厚さ 揚げの時間なども関係してくるであろう。

\section{要約}

1. 鯨肉を末変敗大豆油および変敗油で,それぞれ170 ${ }^{\circ} \mathrm{C}$ で 4 分間揚げ, 值ちにエーテルにて 3 回洗桜したもの と, 完全に脱脂した鯨肉についてパンクレアチンで, 消 化性および消化率を調へた結果，生觡肉よりも油揚げ鍄 肉の方が消化性および消化率が共に良く，また未変敗油 
钴肉よりも変敗油敦肉の方が消化性および消化率良く， 変敗度が高くなるにしたがい，徐々に消化性はよくな り，過酸化物価 200 をこえると逆に消化性は悪くなって いった。

2. 水に対する溶解率は生鲸肉に比べ，末変敗油鯨肉 は半娍し、さらに変敗油鲸肉の方が減少率が大きい。 溶液の $\mathrm{pH}$ は変敗油鲸肉程, 酸性側にあった。

3. 各処理鲸肉中のシスチン量は, 生鯨肉に比べ油揚 げ㝇肉の方が減少し，さらに変敗油鲸肉の方が減少率が 大きい。

4. SH 基は油揚げ処理により鯨肉中に多く出現した が, 末変敗油鲸肉の方が変敗油鲸肉よりも多く出現し た。

\section{文南}

1) 暒本：本誌 12, (1960), 13, (1961)

2) W. B. Hardy: J. Physiol., 24, 158 (1899)

3) H. Chich, C. J. Martin: J. Physiol., 40, 404 (1910). ibid., 43, 1 (1911)

4) H. Wu: Chinese J. Physiol., 5, 321 (1931)

5) M. L. Anson: The Chemistry of the Amino Acid and Proteins.

6) K. Linderström-Lang: Annual Review of Biochemistry, vol. 8, p. 45 (1939)

7) H. P. Lundgren: J. Biol. Chem. 183, 293(1941)

8) 大東：本誌：13. (1961), 12, (1959)

9) H. S. Grindley: U. S. Dept. of Agr., Bulletin, 193 (1907)

10) J. Talarico: Compt. rend. soc. biol. 68, 662, 932 (1910)

11) F. Haurowitz: J. Biol. Chem., 157, 621 (1945)

12）Cohn:食物化兴，共立全监

(神戸慗女子短期大学)
III ヒドロキシメチルピリミジンのピロリン酸エステル の生成

睛母におけるビタミン $\mathrm{B}_{1}$ の生合成の機序はおおむね明 らかになったが，その中最初の反応

Hydroxymethyl pyrimidine + ATP

$\rightarrow$ hydroxymethylpyrimidine - PP

についてはなお不明の点が多かった。

考えられるこ上は hydroxymethylpyrimidine に与 えられるPPが, (a) ATPから直接与えられるか, (口二 段のカロリン酸段階を経て与えられるかであるが, 本研 究の結果，後者によることが判明した。すなわち

Hydroxymethylpyrimidine + ATP $\rightarrow$

hydroxymethylpyrimidinemonophosphate

(1)

Hydroxymethylpyrimidinemonophosphate +

ATP $\stackrel{\mathrm{Mg}^{++}}{\longrightarrow}$ hydroxymethylpyrimidine pyrophosphate (2)
(1) には hydroxymethylpyrimidine kinase

(A) が関与し，(2)にはhydroxymethylpyrimidine phosphokinase (B) が関与する。(A) は $55^{\circ} 10$ 分間の 加熱に安定であるが，（B）不安定。また p-hydroxy・ mercuric benzoate 処理に (A) は安定 (B) は不安 定。ATP以外の nucleosidetriphosphate (A) は 利用できるが(B) は利用できない。

The Biosynthesis of Thiamine.

III Mechanism of Enzymatic Formation of the Pyrophosphate Ester of 2-Methyl-4-amino-5-hydroxymethylpyrimidine.

by L. M. Lewin and G. M. Brown.

J. Biol.Chem., 236, 2768 (1961) 